\title{
ISOLASI DAN IDENTIFIKASI BAKTERI RESISTEN MERKURI DARI MUARA SUNGAI SARIO YANG DAPAT DIGUNAKAN UNTUK DETOKSIFIKASI LIMBAH MERKURI
}

\author{
Fatimawali $^{1)}$, Fatmawaty Badaruddin ${ }^{2)}$, Irawan Yusuf ${ }^{2)}$ \\ ${ }^{1)}$ Dosen Fakultas Kedokteran Unsrat Manado dan Mahasiswa Program Doktor \\ Fakultas Kedokteran Universitas Hasanuddin Makassar \\ ${ }^{2)}$ Dosen Fakultas Kedokteran Universitas Hasanuddin Makassar
}

\begin{abstract}
ABSTRAK
Merkuri adalah logam berat yang bersifat sangat toksik, mempunyai afinitas terhadap gugus thiol protein. Keberadaan merkuri dilingkungan, karena secara alamiah maupun karena aktifitas antrofogenik. Di Kabupaten Bolaang Mongondow terdapat beberapa penambang emas rakyat yang menggunakan merkuri untuk mengekstrak emas dari batuan atau ore dan membuang limbah merkuri secara bebas ke lingkungan dan terbawa air hujan sampai kepada perairan. Sedimen perairan yang terkontaminasi merkuri dapat ditumbuhi bakteri resisten merkuri. Bakteri resisten merkuri anorhanik dapat digunakan untuk bioremediasi perairan, karena bakteri tersebut mampu mereduksi merkuri anorganik menjadi logam merkuri yang mudah menguap dan kurangtoksik. Dan merupakan sumber pencemaran merkuri. Bakteri resisten merkuri mempunyai operon mer yang biasanya terkandung dalam plasmid. Penelitian ini bertujuan untuk mengisolasi bakteri resisten merkuri anorganik, dan menganalisis kemampuannya dalam mereduksi $\mathrm{HgCl}_{2}$ dalam media nutrient broth. Bakteri resisten merkuri tinggi, dilakukan analisis Gen 16S rRNAnya untuk mengetahuis pesiesnya. Hasil penelitian menunjukkan bahwa isolat A1.1.1 merupakan bakteri spesies Klebsiella pneumoniae, mampu mereduksi $\mathrm{HgCl}_{2} 75 \%$ dalam waktu 1 jam, $92 \%$ dalam waktu 12 jam dan 99,4\% dalam waktu 24 jam
\end{abstract}

Kata Kunci: bakteri, detoksifikasi, $\mathrm{HgCl}_{2}$, Klebsiella pneumoniae

\section{ISOLATION AND IDENTIFICATION OF MERCURY-RESISTANT BACTERIUM FROM SARIO RIVER ESTUARY THAT CAN BE USED TO DETOXIFY INORGANIC MERCURY WASTES}

\begin{abstract}
Mercury $(\mathrm{Hg})$ is well known for its high toxicity and strong affinity toward the thiol group of proteins. When $\mathrm{Hg}$ released into the environment in substantial quantities through natural events and anthropogenic activities. In District of Bolaang Mongondow, many miners who are a source of mercury pollution of aquatic environments to which they use to extract gold from the rock or ore. Waters sediment contaminated with mercury, can be overgrown with microorganism such as bacteria that are resistant to mercury. Mercury-resistant bacteria can be used for bioremediation of waters due to the ability of these bacteria to reduce toxic inorganic mercury into mercury metal which is volatile and less toxic. Mercury-resistant bacteria has mer Operon which usually contained in the plasmid. The aim of this study was the selection of bacterial strains resistant to inorganic mercury, as well as to show their capacity to reduce mercury in pure culture media Nutrient Broth. Twelve isolate bacteria was selected for its capacity to reduce mercury $\mathrm{HgCl}_{2}$ in culture media nutrient broth. The one bacterial strains belong to the spesies Klebsiella pneumoniae. Inoculated in pure culture, these strain showed a mercury reduction of $75 \%$ in 1 hour, $92 \%$ in 12 hours, and 99,4\% in 24 hours.
\end{abstract}

Keywords : bacteria , detoxification, $\mathrm{HgCl}_{2}$, Klebsiella pneumoniae

\section{PENDAHULUAN}

Pelepasan logam berat ke lingkungan dapat membahayakan ekosistem menyebabkan bahaya serius pada kesehatan manusia. Merkuri merupakan salah satu logam berat yang paling berbahaya dan 
berada di lingkungan dalam berbagai bentuk. Senyawa merkuri dalam bentuk $\mathrm{Hg}$ (II) dapat terikat pada residu sistein protein manusia sehingga protein akan kehilangan aktivitasnya. Selain $\mathrm{Hg}(\mathrm{II})$, senyawa merkuri yang paling berbahaya bagi kesehatan manusia adalah senyawa merkuri organik, khususnya metil merkuri dan fenil merkuri. Senyawa ini sangat reaktif dan mempunyai mobilitas tinggi dibandingkan $\mathrm{Hg}(0)$ dan $\mathrm{Hg}(\mathrm{II})$, juga dapat menyerang saraf manusia melalui peredaran darah (Rasmussen et al., 2008).

Sumber pencemaran merkuri dapat berasal dari proses geologi dan biologi, tapi tidak sebanding dengan pencemaran merkuri yang disebabkan oleh aktivitas manusia seperti: pembakaran batubara, jenis-jenis produk minyak bumi, penggunaan fungisida, katalisator merkuri dan penambangan emas yang menggunakan merkuri sebagai bahan pengekstraksi emas.

Salah satu usaha untuk detoksifikasi merkuri dapat dilakukan dengan menggunakan mikroorganisme resisten merkuri seperti bakteri resisten merkuri. Detoksifikasi merkuri oleh bakteri resisten merkuri terjadi karena bakteri resisten merkuri memiliki gen resisten merkuri, operon mer (Silver and Phung, 1998). Struktur operon mer berbeda untuk setiap jenis bakteri. Umumnya struktur operon mer terdiri dari gen metaloregulator (merR), gen transfor merkuri (merT, merP, merC), gen merkuri reduktase (merA) dan organo merkuri liase $(m e r B)$. Bakteri yang hanya memliki gen merkuri reduktase (merA) disebut bakteri resisten merkuri spectrum sempit. Ada beberapa bakteri yang memiliki selain gen merA, juga gen merB maka bakteri tersebut disebut bakteri resisten merkuri spectrum luas. Protein MerA mempunyai fungsi mereduksikan ion merkuri yang toksik menjadi logam merkuri $\mathrm{Hg}(\mathrm{O})$ yang kurang toksik dan mudah menguap pada suhu kamar, sedangkan protein MerB mempunyai fungsi mengkatalisis pemutusan ikatan merkurikarbon sehingga dihasilkan senyawa organik dan ion $\mathrm{Hg}$ (II) (Tamar Barkay, 2003).

$$
\text { Beberapa penelitian telah }
$$
mengungkap bahwa mikroorganisme pada daerah tercemar merkuri berperan utama dalam detoksifikasi merkuri, oleh karena itu mikroorganisme pada daerah tercemar merkuri merupakan sumber untuk isolasi bakteri resisten merkuri.

Salah satu masalah di Sulawesi Utara adalah kontaminasi tanah atau air oleh logam merkuri dari hasil buangan limbah tambang emas rakyat yang menggunakan merkuri sebagai bahan pengekstrak emas. Dalam air dan tanah, logam merkuri akan mengalami perubahan spesies menjadi ion merkuri yang larut dalam air dan mencemari perairan. Oleh karena itu pada penelitian ini telah diisolasi bakteri resisten merkuri spektrum sempit dari daerah tercemar merkuri yaitu daerah muara sungai Sario yang terletak di Manado Sulawesi Utara.

\section{Tujuan Penelitian}

Mengisolasi dan mengidentifikasi bakteri resisten merkuri spektrum sempit dari muara Sungai Sario di Manado Sulawesi Utara.

\section{Manfaat Penelitian}

Hasil penelitian ini dapat digunakan untuk detoksifikasi (remediasi) limbah merkuri anorganik di lingkungan perairan.

\section{METODOLOGI PENELITIAN}

\section{Alat dan bahan yang digunakan}

Sarung tangan steril, tabung Durham, Skop kecil, Lampu spiritus, Plastik steril, incubator, mikroskop, kaca slide, jarum Ose, CV-AAS, Laminar Air Flow, Alat-alat gelas, Timbangan Sartorius, Freezer.Kit Ekstraksi Wizard Genomic DNA (Promega): EDTA ,Lytic enzyme, Larutan nuclei lysis, Larutan RNA ase, Larutan protein precipitation, isopropanol, etanol 70\%, Larutan DNA rehydration. Primer Bact-FI .5'AGAGTTTGATCMTGGCTCAG3'/UniB1.5'GGTTACSTTGTTACGACTT3'

(Eurogentic AIT), agarose (Vivantis), Etidiumbromida, loading dye (Vivantis), marker (Vivantis).

\section{Pengambilan Sampel}

Sampel sediment diambil dari tiga titik A1, A2 dan A3. Isolat pada setiap titik ke dalam larutan $\mathrm{NaCl} 0,9 \%$ yang telah dibuffer. Selanjutnya diinokulasi pada media nutrient broth dengan konsentrasi $\mathrm{HgCl}_{2} 5$, 
10, 20, dan $40 \mathrm{mg} / \mathrm{l}$. Diinkubasikan pada suhu $30^{\circ} \mathrm{C}$ selama 24 jam. Kultur yang tumbuh pada media dengan konsentrasi merkuri tertinggi, digunakan untuk identifikasi dan pengujian daya reduksinya terhadap $\mathrm{HgCl}_{2}$.

\section{Uji Daya Reduksi Merkuri dari Bakteri Resisten Merkuri}

Diambil 1 ose Bakteri resisten merkuri tinggi dari media agar miring. Ditanam dalam media nutrient broth yang mengandung $2 \mathrm{ppm} \mathrm{HgCl}_{2}$. Diinkubasi pada suhu $37^{\circ} \mathrm{C}$ selama 1 jam, 12 jam dan 24 jam. Pada akhir inkubasi, ditambahkan $\mathrm{H}_{2} \mathrm{SO}_{4}$ pekat 2 tetes untuk membunuh bakteri yang selanjutnya dianalisis kadar merkuri dengan metode analisis CVAAS dan dilakukan analisis blanko.

\section{Isolasi DNA Genomik}

Isolasi DNA Genomik dilakukan sesuai metode Wizard Genomic DNA (Promega). Sampel kultur bakteri diambil 1 ose ditambah $1 \mathrm{ml}$ aquades steril dalam tabung mikrosentrifus $1,5 \mathrm{ml}$, dibiarkan semalam. Sampel disentrifus dengan kecepatan $13.000 \mathrm{rpm}$ selama 2 menit, supernatant dibuang. Ditambahkan $600 \mu \mathrm{l}$ larutan lisis nuclei, dikocok dengan pipet agar sel-sel tersuspensi. Sampel diinkubasi pada suhu $80^{\circ} \mathrm{C}$ selama 5 menit supaya sel lisat. Di bolak-balik tabungnya supaya tercampur. Sampel diinkubasi pada suhu $37^{\circ} \mathrm{C}$ selama 30 menit, didinginkan pada suhu kamar. Sampel ditambahkan $200 \mu \mathrm{l}$ larutan protein presipitat, divortex pada kecepatan tinggi selama 20 detik untuk mencampur protein presipitat dengan sel lisat. Sampel diinkubasi selama 5 menit, disentrifus pada $13.000 \mathrm{rpm}$ selama 3 menit. Supernatan dipindahkan ke dalam tabung mikrosentrifus. Sampel ditambahkan $600 \mu 1$ isopropanol, dicampur dengan membolak-balik tabung. Sampel disentrifus pada 13.000 rpm selama 2 menit, Supernatant dibuang dan tabung dikeringkan dengan membalikkan di atas kertas tissue. Sampel ditambahkan $600 \mu \mathrm{l}$ etanol $70 \%$ dan dikocok dengan membolak-balikkan tabung beberapa kali untuk mencuci DNA. Sampel disentrifus pada $13.000 \mathrm{rpm}$ selama 2 menit, isi tabung dituang dan dikeringkan di atas kertas tissue, dibiarkan 10-15 menit (kering-anginkan), ditambahkan $100 \mu$ larutan DNA rehidrasi ke dalam tabung, diinkubasi pada suhu $4^{\circ} \mathrm{C}$ semalam. DNA disimpan pada suhu $2-8^{\circ} \mathrm{C}$.

\section{Amplifikasi Gen 16S rRNA dengan Teknik PCR}

Amplifikasi dilakukan dengan menggunakan mesin PCR Combi Block (Whatman Biometra Germany). Primer yang digunakan untuk proses PCR yaitu pasangan primer universal Bact F1 (forward) dan Uni $\mathrm{B} 1$ (reverse). Cetakan yang digunakan untuk amplifikasi gen 16S rRNA adalah DNA genomik bakteri yang telah diisolasi. Amplifikasi dengan teknik PCR dilakukan dengan variasi komposisi reagen dan kondisi reaksi PCR seperti dibawah ini.

\begin{tabular}{|c|c|}
\hline Komposisi reagen untuk $P$ & $16 S$ \\
\hline Untuk 1 Tabung PCR: & \\
\hline $\mathrm{ddH}_{2} \mathrm{O}$ & $15,8 \mu \mathrm{l}$ \\
\hline Bufer PCR 10x & $2,5 \mu 1$ \\
\hline $\mathrm{MgCl}_{2} 25 \mathrm{mM}$ & $3,0 \mu \mathrm{l}$ \\
\hline $\mathrm{dNTP} 10 \mathrm{mM}$ & $0,5 \mu \mathrm{l}$ \\
\hline Primer UniBI $30 \mathrm{pmol} / \mu \mathrm{l}$ & $1,0 \mu \mathrm{l}$ \\
\hline Primer BactFI $30 \mathrm{pmol} / \mu \mathrm{l}$ & $1,0 \mu \mathrm{l}$ \\
\hline Taq DNA Pol $(5 \mathrm{U} / \mu \mathrm{l})$ & $0,2 \mu 1$ \\
\hline Templat (pengenceran 10x) & $1,0 \mu 1$ \\
\hline Total & $25,0 \mu l$ \\
\hline
\end{tabular}

Tabung PCR yang telah berisi campuran reaksi dimasukkan ke dalam mesin PCR yang diprogram sebagai berikut :

$\begin{array}{lll}\text { Kondisireaksi PCR gen 16S rRNA: } \\ \text { Denaturasiawal } 94^{\circ} & 3^{\prime} & \\ \text { Denaturasi } & 94^{\circ} & 1,30 \text { siklus } \\ \text { Annealing } & 62^{\circ} & 1,30^{\prime \prime} \\ \text { Polimerisasi } & 72^{\circ} & 1,30^{\prime \prime} \\ \text { Pemantapan } & 72^{\circ} & 10^{\prime}\end{array}$

\section{Elektroforesis dan Visualisasi gen $16 S$ rRNA}

DNA yang telah diamplifikasi, diseparasi dengan elektroforesis gel agarosa $1 \%$, selanjutnya dilakukan visualisasi menggunakan pewarna etidium bromida dan dideteksi dengan sinar UV pada $U V$ transiluminator. Hasil deteksi didokumentasikan. 


\section{Sekuensing gen $16 S$ rRNA}

Sekuensing dilakukan untuk menentukan urutan nukleotida pada fragmen DNA yang terdeteksi dari hasil visualisasi DNA yang teramplifikasi dalam proses PCR menggunakan mesin sekuensing DNA otomatis. Proses sekuensing dilakukan di Macrogen Korea. Hasil sekuensing DNA dianalisis menggunakan metode BLAST melalui media Online NCBI, untuk mencari kesamaan urutan nukleotida gen 16S rRNA dalam menentukan spesies bakteri resisten merkuri anorganik yang diisolasi dari lokasi tercemar merkuri.

\section{HASIL DAN PEMBAHASAN}

\section{a. Isolasi Bakteri Resisten Merkuri Anorganik}

Pada hasil isolasi bakteri resisten merkuri anorganik ini, isolate ditumbuhkan dalam nutrient broth yang mengandung $\mathrm{HgCl}_{2}$ dengan konsentrasi yang berbeda (5, $10,20,40) \mathrm{mg} / \mathrm{l}$. Hasil yang didapat pada setiap isolate dapat dilihat pada Tabel 1 . Pada konsentrasi $5 \mathrm{mg} / \mathrm{l}$, diperoleh 12 isolat, 10 dan $20 \mathrm{mg} / \mathrm{l}$ diperoleh hanya 1 isolat yaitu A1.1.1, sedangkan pada konsentrasi $40 \mathrm{mg} / \mathrm{l}$, tidak ada pertumbuhan bakteri.

Tabel 1.Hasil Isolasi Bakteri Resisten Merkuri Anorganik

\begin{tabular}{|c|c|c|c|c|}
\hline \multirow{2}{*}{ KodeUji } & \multicolumn{4}{|c|}{ Konsentrasi $\mathrm{HgCl}_{2}(\mathrm{mg} / \mathrm{l})$} \\
\cline { 2 - 5 } & 5 & 10 & 20 & 40 \\
\hline A1.1.1 & + & + & + & - \\
\hline A1.1.2 & + & - & - & - \\
\hline A1.1.3 & + & - & - & - \\
\hline A1.1.4 & + & - & - & - \\
\hline A1.1.5 & + & - & - & - \\
\hline A1.2.1 & + & - & - & - \\
\hline A2.1.1 & + & - & - & - \\
\hline A3.2.1 & + & - & - & - \\
\hline A 3.3.1 & + & - & - & - \\
\hline A 3.3.2 & + & - & - & - \\
\hline A 3.3.4 & + & - & - & - \\
\hline A 3.3.4 & + & - & - & - \\
\hline
\end{tabular}

Tabel 2.HasilAnalisisDayaReduksiMerkuriIsolat A1.1.1

\begin{tabular}{|l|c|l|l|l|c|l|c|l|c|}
\hline \multirow{2}{*}{ No. } & \multirow{2}{*}{ Perlakuan } & \multicolumn{7}{|c|}{ Kadar $\mathrm{Hg}(\mathrm{mg} / \mathrm{l})$} \\
\cline { 3 - 11 } & & 0 jam & $\%$ & 1 jam & $\%$ & 12 jam & $\%$ & 24 jam & $\%$ \\
\hline 1. & Kontrol Media NB & 0 & 0 & 0 & 0 & 0 & 0 & 0 & 0 \\
\hline 2. & Kontrol $\mathrm{HgCl} 2$ & 1.53 & 100 & 1.53 & 100 & 1.53 & 100 & 1.53 & 100 \\
\hline 3. & $\mathrm{~A} 1.1 .1$ & 1.53 & 100 & 0.38 & 25 & 0.12 & 8 & 0.01 & 0.6 \\
\hline
\end{tabular}

\section{b. Uji Daya Reduksi Merkuri dari Bakteri Resisten Merkuri}

Menurut Vetriani et al., (2004), bakteri resisten merkuri tinggi mengandung operon mer yang mengkode flavoenzim, merkuri reduktase yang dapat mereduksi ion $\mathrm{Hg}^{2+}$ menjadi $\mathrm{Hg}^{0}$ yang kurang toksik. Pada penelitian ini telah dilakukan uji daya reduksi merkuri bakteri yang resisten merkuri tinggi yaitu A1.1.1. Kultur ditumbuhkan dalam media nutrien broth yang mengandung $\mathrm{HgCl}_{2} 2 \mathrm{mg} / \mathrm{l}$ (Hg 1,5 mg/l) selama $1 \mathrm{jam}$, 12 jam dan 24 jam, dilakukan juga analisis kontrol $\mathrm{HgCl}_{2}$ dan media. Analisis dilakukan dengan metode analisis CV-AAS. Hasil analisis menunjukkan bahwa isolat bakteri resisten merkuri anorganik A1.1.1 dapat menurunkan kadar $\mathrm{Hg}$ dalam waktu 1,12 dan 24 jam. Hasil pengukuran konsentrasi merkuri terlihat pada Tabel 2 . 
Penurunan kadar merkuri dalam media dalam Gambar 1. waktu 1, 12 dan 24 jam ditunjukkan pada

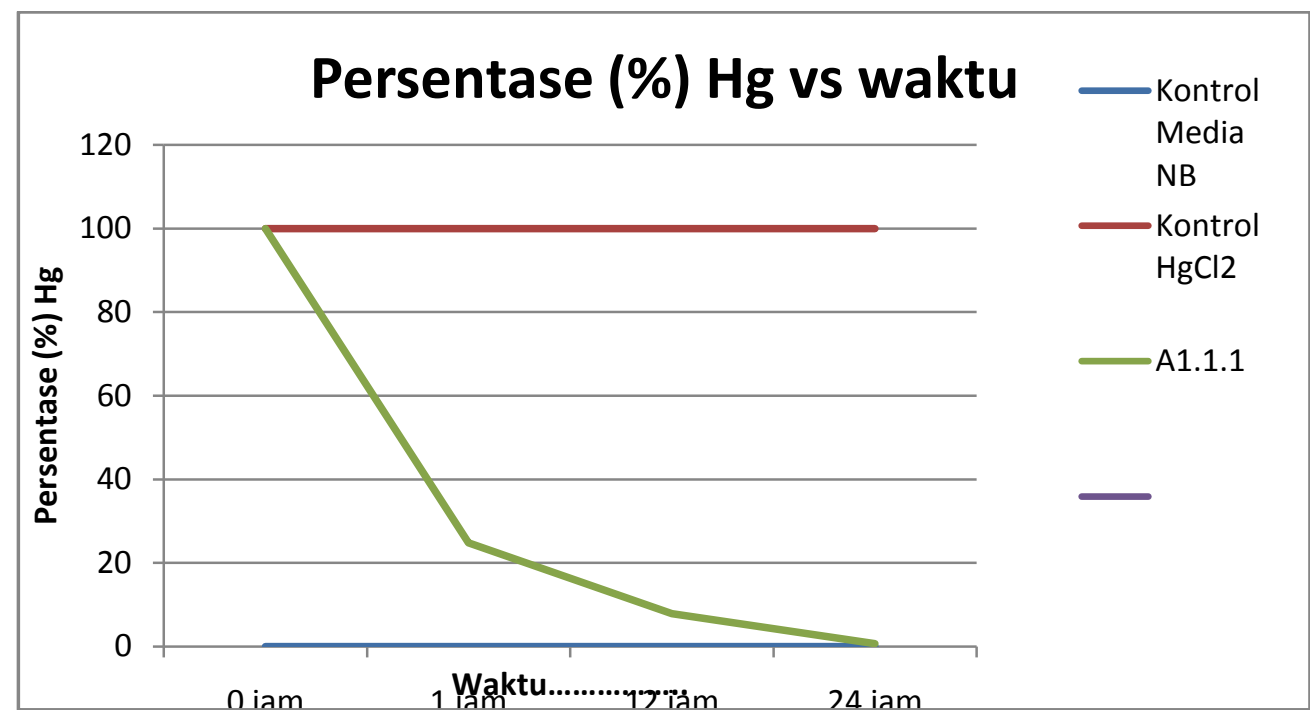

Gambar 1. Grafik Penurunan kadar merkuri (\%) vs Waktu

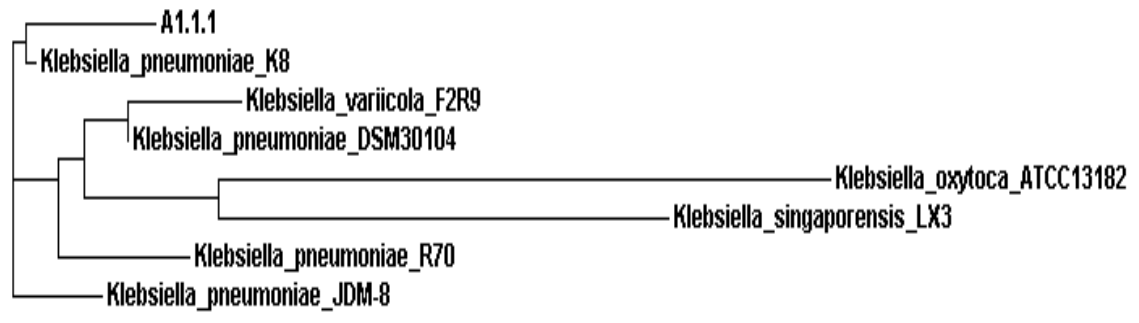

Gambar 2. Pohon Filogenik Hasil Penjajaran Gen 16S rRNA isolat A1.1.1

\section{c. Analisis Gen 16S rRNA Bakteri resisten Merkuri Anorganik}

Hasil isolasi DNA isolat A1.1.1 diamplifikasi menggunakan PCR kemudian dielektroforesis dengan agarose $1,5 \%$. Hasil menunjukkan adanya pita gen $16 \mathrm{~S}$ rRNA pada 1500 bp. Hasil amplifikasi kemudian disekuensing pada Macrogen Korea. Hasil sekuensing gen 16S rRNA isolat A1.1.1 ditunjukkan pada Gambar 2.

Urutan nukleotida hasil sekuensing gen 16S rRNA isolat A1.1.1, selanjutnya dilakukan Blast melalui online NCBI. Hasil Blast menunjukkan kesamaan 99\% dengan Klebsiella pneumoniae, Klebsiella variicola, Klebsiella singaporensis dan Klebsiella oxyloca. Pohon filogenik yang menggambarkan hubungan kekerabatan isolat
A1.1.1 dengan Klebsiellalain yang ada pada Gen Bank (Gambar 2). Terlihat Bahwa isolat A1.1.1 berkerabat dekat dengan Klebsiella pneumoniae galur K8, Klebsiella pneumoniae galur JDM8, Klebsiella pneumoniae galur R70 dan Klebsiella pneumoniae galur DSM30104, oleh karena itu, dapat disimpulkan bahwa isolat A1.1.1 adalah jenis Klebsiella pneumoniae berdasarkan analisis Gen 16S rRNA.

\section{KESIMPULAN DAN SARAN}

\section{Kesimpulan}

Dari hasil penelitian diperoleh bahwa perairan di Sulawesi Utara yaitu di muara Sungai Sario, terdapat bakteri resisten merkuri yang dapat mereduksi merkuri 
anorganik $\mathrm{HgCl}_{2}$ menjadi $\mathrm{Hg}^{0}$ yang mudah menguap sehingga dapat digunakan untuk detoksifikasi limbah merkuri.

Berdasarkan hasil analisis gen $16 \mathrm{~S}$ rRNA, bakteri resisten merkuri isolat A1.1.1 merupakan bakteri jenis Klebsiella pneumoniae.

\section{Saran}

Dari hasil penelitian, dapat disarankan untuk dilakukan analisis lebih lanjut terhadap gen yang bertanggung jawab terhadap reduksi merkuri yaitu gen merA untuk mendapatkan enzim merA yang dapat dikloning dan digunakan dalam remediasi limbah merkuri.

\section{DAFTAR PUSTAKA}

Barkay, T., and I. Wagner-Dobler. 2005. Microbial Transformations of Mercury: Potentials, challenges, and achievements in controlling mercury toxicity in the environment. Adv. Appl. Microbiol. 57: 1-52.

Barkay, T., S.M. Miller, A.O. Summers. 2003. Bacterial Mercury Resistance from Atoms to Ecosystems. FEMS Microbiol. Rev. 27:355-384

Diner, M. B. and E.B. Brenner. 2007. Toxicology Mercury. Article Last Updated, Department of Emergency Medicine, Emory University School of Medicine; clinical researcher, Emergency Medicine Research Center.

Fatimawali, B. Kepel, B. Fatmawaty, Irawan Yusuf, R. Natsir. 2009. Populasi Bakteri pada Tanah Bekas Buangan Limbah Merkuri Tambang Emas di Kabupaten Bolaang Mongondow: Penelitian Pendahuluan, Jurnal Kedokteran Yarsi, Vol. 17 No.2.

Holt, J.G., N.R. Krieg, P.H.A. Sneath, J.T. Staley, S.T. Williams. 1994. Bergey's Manual of Determinative Bacteriology, $9^{\text {th }}$ Edition. USA: Williams and Wilkins.
Huang, C.C., M.W. Chen, J.L. Hsieh, W.H. Lin, P.C. Chen, and L.F. Chien. 2006. Expression of Mercuric Reductase from Bacillus Megaterium MB1 in Eukaryotic Microalga chlorella sp. DT: an Approach for Mercury Phytoremediation. Appl. Microbiol. Biotechnol. 72: 197-205.

Ijong, F. G. 2003. Mikrobiologi Dasar. Laboratorium Mikrobiologi Hasil Perikanan, Fakultas Perikanan dan Ilmu Kelautan UNSRAT, Manado.

Iohara, K., R. Iiyama, K. Nakamura, S. Silver, M. Sakai, M. Takeshita, and K. Furukawa. 2001. The Mer operon of a mercury-resistant Pseudoalteromonas haloplanktis strain isolated from Minamata Bay, Japan. Appl. Microbiol. Biotechnol. 56: 736-741.

Nofiani, R., Gusrizal. 2004. Bakteri Resistensi Merkuri Spektrum Sempit dari Daerah Bekas Penambangan Emas Tanpa Izin (PETI) Mandor Kalimantan Barat. JNI, 6(2): 67-74.

Poulin, A. J., S. Chadchain, P.A. Ariya, M. Amot, E. Garcia, P.G.C. Campbell, G.J. Zylstra, and T. Barkay. 2007. Potential for Mercury Reduction by Microbes in the High Arctic. Appl. Environ. Microbiol. 73(7):2230-2238.

Rasmussen, L. D., C. Zawadsky, S.J. Binnerup, G. Oregaard, S.J. Sorensen, and N. Kroer. 2008. Cultivation of Hard-To-Culture Subsurface MercuryResistant Bacteria and Discovery of New merA Gene Sequences, Department of Environmental Chemistry and Microbiology, National Environmental Research Institute, University of Aarhus, Frederiksborgvej 399, 4000 Roskilde, Denmark, Institute of Biology, University of Copenhagen, Solvgade 83H, 1307 Copenhagen K, Denmark. App. Environ. Microbiol. p.3795-3803, vol. 74, No.12.

Silver, S. and L.T. Phung. 1996. Bacterial Heavy Metal Resistance: New suprises. Annu. Rev. Microbiol. 50: 753-789. 
Simbahan, J. M., E. Kurth, J. Schelert, A. Dillman, E. Moriyama, S. Jovanovich, and P. Blum. 2005. Mercury Hot Spring Supports Occurrence of DomainSpecific Forms of Mercuric Reductase. Appl. Environ. Microbio. 71(12):8836-8845.

Vetriani, C., Y.S. Chew, S.M. Miller, J. Yagi, J. Coombs, R.A. Lutz, and T. Barkay. 2005. Mercury Adaptation among Bacteriafrom a Deep-sea Hydrothermal Vent. Appl. Environ. Microbiol. 71(1):220-226. 